\title{
Artificial Lighting During Winter Increases Milk Yield in Dairy Ewes
}

\author{
A. D. Morrissey, A. W. N. Cameron, and A. J. Tilbrook ${ }^{1}$ \\ Department of Physiology, Monash University, Clayton, Victoria, 3800, Australia
}

\begin{abstract}
In Australia, the supply of sheep milk is reduced during the winter. Housing dairy animals under lights during winter is a simple technique to increase milk yield; however, it is difficult to predict the magnitude of this increase in dairy ewes, because there are few corroborating data. We studied 220 East Friesian crossbred ewes (50 primiparous and 170 multiparous ewes, respectively) that lambed in April to May 2007 (late autumn, southern hemisphere) and were weaned from their lambs within $24 \mathrm{~h}$ of parturition and milked exclusively by machine. These ewes were ranked according to their milk production, and ewes producing $\geq 1,000 \mathrm{~mL} / \mathrm{d}$ of milk were allocated to 1 of 2 groups. One group of ewes was kept indoors under a long-day photoperiod (16 h of light), whereas the other group was kept indoors under a naturally declining day length. Ewes were maintained under these conditions for $8 \mathrm{wk}$. Milk yield was measured twice weekly, and ewe weight and condition were measured at weekly intervals. From a subset of ewes (n $=20$ per group), milk samples were collected twice weekly at the morning milking to measure milk lipid, protein, and lactose, and blood samples were collected once a week to measure plasma prolactin concentrations. Mean daily milk yield was analyzed as a percentage of preexperimental milk yield because the milk yield of ewes housed under the long photoperiod was lower than that of ewes under a declining day length when the treatments began. Thus, the ewes under a long photoperiod yielded $91.7 \%$ of their starting yield by wk 8 of treatment, whereas ewes under a declining day length yielded $76.25 \%$ of their initial value (LSD $=5.1$ ), and this divergence in milk yield was apparent by wk 2 of treatment. Mean plasma prolactin levels were greater in ewes housed under the long-day photoperiod $(\mathrm{n}=20)$ compared with control ewes $(\mathrm{n}=20)$ at wk $6(168 \pm 27$ vs. $72 \pm 19 \mathrm{ng} /$ $\mathrm{mL}$, respectively), wk 7 (125 \pm 28 vs. $37 \pm 7 \mathrm{ng} / \mathrm{mL}$, respectively), and wk 8 of the experiment (132 \pm 35 vs. 31 $\pm 7 \mathrm{ng} / \mathrm{mL}$, respectively). The composition of the milk
\end{abstract}

Received December 4, 2007.

Accepted June 26, 2008.

${ }^{1}$ Corresponding author: alan.tilbrook@med.monash.edu.au was similar between the groups at each time point, and milk from these ewes ( $\mathrm{n}=20$ per group) contained, on average, $6.1 \pm 0.05 \%$ lipid, $4.8 \pm 0.02 \%$ protein, and 5.4 $\pm 0.01 \%$ lactose ( $n=309$ samples). We concluded that ewes increase milk production in response to being housed under a long-day photoperiod during winter. Key words: photoperiod, dairy ewe, milk yield

\section{INTRODUCTION}

Milk production in dairy animals is affected by season (Svennersten-Sjaunja and Olsson, 2005), and without manipulation of the photoperiod reaches a nadir during winter. Numerous studies in dairy cows have demonstrated that the imposition of a long-day photoperiod during winter increases milk production by 1 to $3 \mathrm{~L} / \mathrm{d}$ (reviewed by Dahl et al., 2000). In comparison with research in dairy cows, similar basic research in dairy ewes is limited, because all levels of the sheep milk industry, from primary production to processing, remain seasonal in Mediterranean countries (Bencini and Pulina, 1997). Because of this lack of corroborating data, it is uncertain whether manipulation of the photoperiod can be used as a management tool to increase milk production in dairy ewe flocks.

Photoperiod is the cue that entrains the seasonal pattern of reproduction in sheep. Sheep measure photoperiodic time by using a circadian rhythm of photosensitivity (Ortavant et al., 1988; Woodfill et al., 1994); in particular, the pattern of melatonin secretion around the summer solstice (Barrell et al., 2000) entrains the circannual pattern of reproduction, lactation, and energy metabolism of the ewe. Perhaps not surprisingly, milk yield in Awassi ewes and their crosses that are intensively managed and milked year round varies according to the month of the year, and this has been attributed to the effects of photoperiod and heat load (Gootwine and Pollott, 2000; Pollott and Gootwine, 2004). The magnitude of the expected increase in milk production is difficult to predict, because our knowledge of the effect of photoperiod on sheep milk production is derived from studies in which sample sizes are small and the design of most experiments expose ewes to a photoperiod treatment before parturition, when the galactopoietic effects of a long-day photoperiod are pos- 
sibly confounded by mammogenic effects, or to diet manipulation (Bocquier et al., 1990, 1997). Nevertheless, an increase in the order of $0.44 \mathrm{~L} / \mathrm{d}$ has been attributed to a long photoperiod (Pollott and Gootwine, 2004).

To maintain a continuous supply of milk, ewes in some Australian dairies are milked year round and are managed to lamb at 9-mo intervals. In this country, milk supply limits the manufacture of sheep milk products (Lindsay and Skerritt, 2003), and manipulation of the photoperiod may be one method of overcoming shortages of milk during the winter (Bencini and $\mathrm{Pu}$ lina, 1997). We have studied groups of East Friesian crossbred ewes that lambed in autumn (southern hemisphere) and were consequently exposed to declining day length at the beginning of lactation. We randomly allocated these ewes to 1 of 2 groups. One group was maintained under a naturally declining day length, and the other group was exposed to a long-day photoperiod (16 h of light and $8 \mathrm{~h}$ of darkness) to test the hypothesis that exposure to a long-day photoperiod during winter, when applied to an established lactation (after the cessation of mammogenesis), may increase milk yield.

\section{MATERIALS AND METHODS}

\section{Animals}

A total of 50 primiparous and 170 multiparous ewes (consisting of 34 second-parity ewes, 52 third-parity ewes, 45 fourth-parity ewes, and 39 fifth-parity or greater ewes) were studied in this experiment. These ewes were part of a self-replacing flock of crossbred ewes (50\% East Friesian, and 50\% predominantly Polled Dorset, White Suffolk, or both) used in a commercial dairy [Meredith Dairy (latitude $37^{\circ} 51^{\prime} 0^{\prime \prime}$ ), Victoria, Australia]. Ewes lambed $36.6 \pm 1.7 \mathrm{~d}$ before this experiment, and ewes were weaned from their lambs within $1 \mathrm{~d}$ of parturition and milked exclusively by machine. Ewes were milked at 0500 and $1700 \mathrm{~h}$ each day in a 10-a-side herringbone dairy with the cups set to provide 160 pulsations/min in a 60:40 ratio with a vacuum of $38 \mathrm{kPa}$. This experiment began on Monday, May 7, 2007, when each experimental group was housed in a separate barn. Ewes were fed ad libitum (consuming approximately $2.8 \mathrm{~kg} /$ ewe per day) a mixture of vetch hay, silage, canola meal, and barley (designed to be $16 \%$ $\mathrm{CP}$ ), and at each milking, ewes received an additional $250 \mathrm{~g}$ of barley. Voluntary food intake, ewe weight, and BCS were measured weekly.

All animal procedures were conducted with prior institutional ethical approval under the requirements of the Australian Prevention of Cruelty to Animals Act 1986 and the National Health and Medical Research Council, Commonwealth Scientific and Industrial
Research Organization, Australian Research Council Code of Practice for the Care and Use of Animals for Scientific Purposes (National Health and Medical Research Council, 2004).

\section{Experimental Design}

Ewes were ranked according to milk yield in the week before the experiment, and ewes producing more than $1 \mathrm{~L} / \mathrm{d}$ were allocated to 1 of 2 groups with similar average daily production. Because of illness, 22 ewes were subsequently excluded from the analysis, and this resulted in a difference between groups in the mean milk production at the start of the experiment $[2,051 \pm$ $672 \mathrm{~mL} / \mathrm{d}$ and $1,887 \pm 672 \mathrm{~mL} / \mathrm{d}$ (mean $\pm \mathrm{SD}$ )] for ewes exposed to a naturally declining photoperiod and $16 \mathrm{~h}$ of light, respectively, $P=0.073$ ). One group ( $\mathrm{n}=110$, including 26 primiparous ewes) was subjected to a naturally declining day length, whereas the other group (n $=110$, including 24 primiparous ewes) was exposed to $16 \mathrm{~h}$ of artificial lighting (500 lx at the eye level of the ewe). Milk volumes ( $\mathrm{mL}$ ) were recorded twice weekly at the morning milking after $12 \mathrm{~h}$ of milk accumulation. The volume of milk was recorded (within $50 \mathrm{~mL}$ ) by using milk meters fitted with goat nozzles (Waikato MK5, Waikato, New Zealand) and was used to calculate daily milk production. From a subset of ewes $(n=20$ per group, same individuals each measurement), samples of milk were collected twice weekly at the a.m. milking. Preservative (potassium dichromate, Normapur, VWR International, Strasbourg, France) was added to each milk sample and samples were then stored at $-20^{\circ} \mathrm{C}$ until analysis. Milk samples were thawed in a water bath $\left(60^{\circ} \mathrm{C}\right)$ and the percentages of lipid, protein, and lactose were measured in duplicate $(10-\mathrm{mL}$ aliquots) by using a Bentley 2000 Infrared Milk Analyzer (Bentley Instruments, Chaska, MN). From the same subset of ewes, blood samples $(7 \mathrm{~mL})$ were collected once a week (at $1100 \mathrm{~h}$ ) by venipuncture, and plasma was separated by centrifugation and stored at $-20^{\circ} \mathrm{C}$. The concentration of prolactin in the weekly plasma samples was measured by using a routine RIA validated for sheep plasma (McNeilly and Andrews, 1974). The sensitivities of this assay were 0.11 and $0.14 \mathrm{ng} / \mathrm{mL}$, and interassay coefficients of variation were $10.1 \%$ at $7.6 \pm 0.5$ $\mathrm{ng} / \mathrm{mL}$ and $9.5 \%$ at $22.8 \pm 1.5 \mathrm{ng} / \mathrm{mL}$, respectively $(2$ assays).

\section{Statistical Analysis}

Data from this experiment were statistically analyzed by using repeated-measures ANOVA. The treatment (naturally declining day length or artificial lighting for $16 \mathrm{~h} / \mathrm{d}$ ) was used as the between-subjects factor for each 


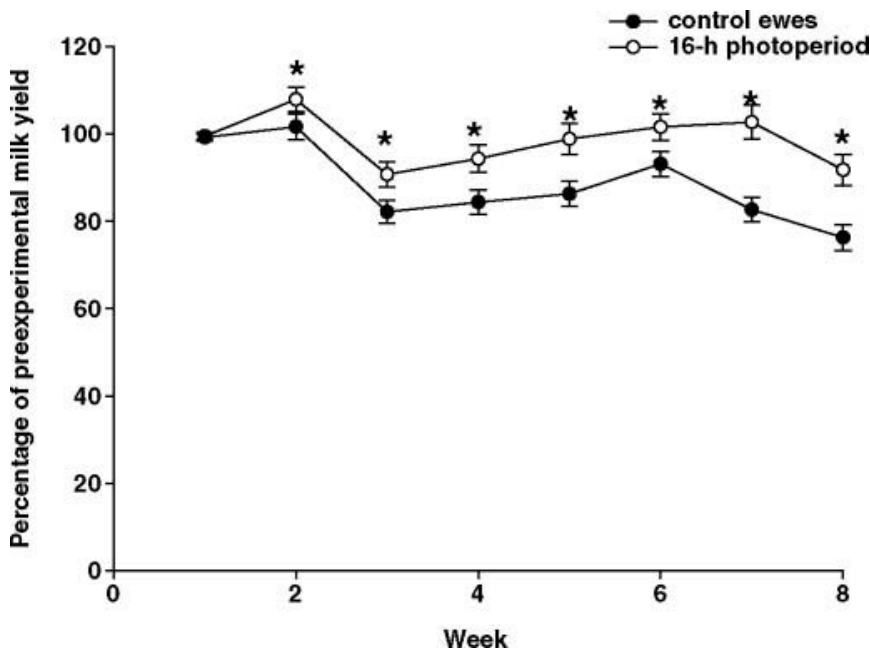

Figure 1. Mean $( \pm$ SEM) daily milk production, expressed as a percentage of preexperimental milk yield (\%), in ewes housed under a 16-h photoperiod and ewes housed under a naturally declining day length, measured during the $8 \mathrm{wk}$ of this experiment. Mean daily milk production (as a percentage of preexperimental milk yield) was affected by time $(P \leq 0.001)$, and differences between the groups at each time point are represented by an asterisk $\left({ }^{*} P<0.05\right)$.

repeated-measures ANOVA. Because the mean milk production from the 2 groups differed at the start of the experiment, the data for milk production were converted to a percentage of the preexperimental milk production. In separate analyses, daily milk yield, plasma prolactin concentration, percentage of lipid, percentage of protein, percentage of lactose, ewe weight, and BCS were used as the within-subjects factors, and when each analysis was performed, the respective error term was considered. Total milk yield ( $8 \mathrm{wk}$ ) and the average rate of decline in milk production were analyzed by using one-way ANOVA, with treatment (naturally declining day length or artificial lighting for $16 \mathrm{~h} / \mathrm{d}$ ) as the between-subjects factor. A priori decisions to exclude ewes $(n=22)$ from analysis were made if ewes became lame, developed mastitis, or had pneumonia. Homogeneity of variance was checked for each set of data, and no transformations were applied. Where appropriate, post hoc comparisons were made by using least significant differences. Data are presented as the mean \pm SEM, and results were considered significant when $P \leq 0.05$.

\section{RESULTS}

Time (week) affected mean daily milk yield $\left[\mathrm{F}_{(7,1372)}\right.$ $=28.370, P \leq 0.001]$, and there was an interaction between time and treatment $\left[\mathrm{F}_{(7,1372)}=5.293, P \leq 0.001\right]$. The mean daily milk yield (as a percentage of the preexperimental milk yield) was greater $(P<0.05)$ in ewes

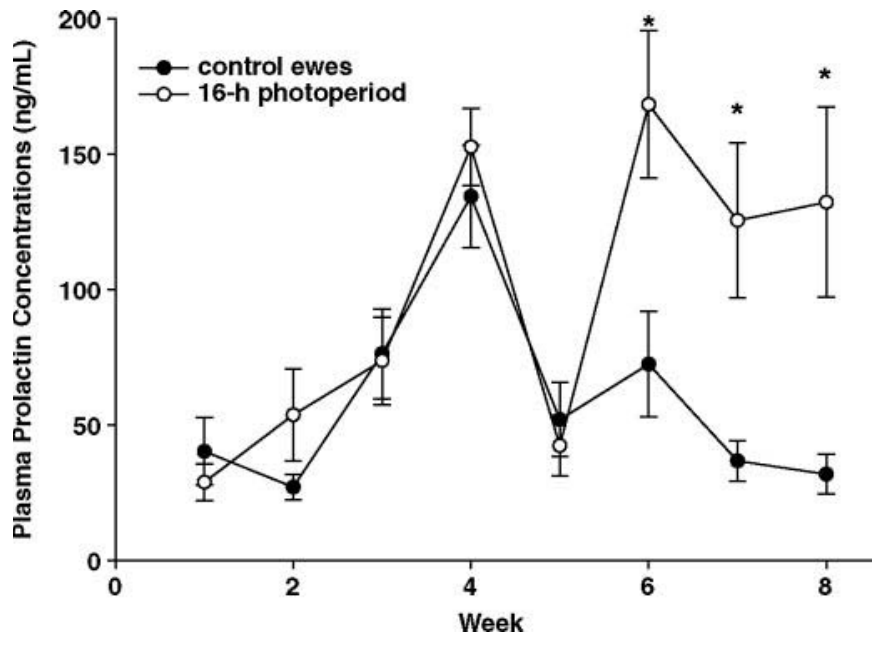

Figure 2. Mean ( \pm SEM) plasma prolactin concentrations $(\mathrm{ng} / \mathrm{mL})$ in ewes housed under a 16 -h photoperiod and ewes housed under a naturally declining day length during the $8 \mathrm{wk}$ of this experiment. Prolactin concentrations were affected by time $(P \leq 0.001)$, and differences between the groups at each time point are represented by an asterisk $\left({ }^{*} P<0.05\right)$.

housed under a long-day photoperiod compared with ewes housed under a naturally declining day length during wk 2 to 8 of the experiment (Figure 1). By wk 8 of the experiment, ewes housed under a long-day photoperiod produced $15.4 \%$ more milk compared with ewes housed under a naturally declining day length.

Time (week) affected mean plasma prolactin concentrations $\left[\mathrm{ng} / \mathrm{mL} ; \mathrm{F}_{(7,266)}=10.596, P \leq 0.001\right]$, and there was an interaction between time and treatment $\left[\mathrm{F}_{(7,266)}\right.$ $=4.261, P \leq 0.001]$. Mean plasma prolactin levels were greater $(P<0.05)$ in ewes housed under a long-day photoperiod $(n=20)$ compared with ewes housed under a naturally declining day length $(\mathrm{n}=20)$ at wk $6(168$ $\pm 27 \mathrm{ng} / \mathrm{mL}$ vs. $72 \pm 19 \mathrm{ng} / \mathrm{mL}$, respectively), wk 7 (125 $\pm 28 \mathrm{ng} / \mathrm{mL}$ vs. $37 \pm 7 \mathrm{ng} / \mathrm{mL}$, respectively), and wk 8 (132 $\pm 35 \mathrm{ng} / \mathrm{mL}$ vs. $31 \pm 7 \mathrm{ng} / \mathrm{mL}$, respectively) of the experiment (Figure 2).

Milk composition remained unaffected by time (week), mean percentage of protein $\left[\mathrm{F}_{(7,224)}=0.829, P=\right.$ $0.564]$, and mean percentage of lactose $\left[\mathrm{F}_{(7,224)}=1.998\right.$, $P=0.058)]$, but the mean percentage of lipid varied according to the week of the experiment $\left[\mathrm{F}_{(7,224)}=\right.$ $18.900, P \leq 0.001$ ], albeit inconsistently. No significant interaction between time and treatment was found for percentage of lipid $\left[\mathrm{F}_{(7,224)}=1.491, P=0.172\right]$, percentage of protein $\left.\left[\mathrm{F}_{(7,224)}=1.661, P=0.120\right)\right]$, or percentage of lactose $\left[\mathrm{F}_{(7,224)}=1.611, P=0.133\right]$. These data are presented (Figure 3) after removing treatment as a between-subjects factor. After combining the data on milk composition by removing week and treatment as between-subjects factors, milk from these ewes $(\mathrm{n}=$ 


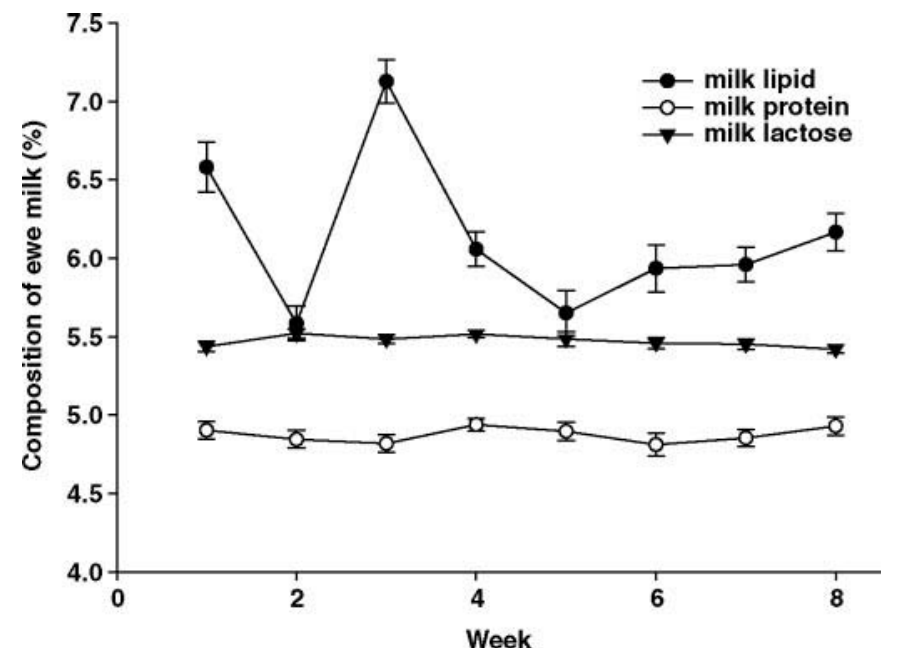

Figure 3. Mean ( \pm SEM) percentages of lipid, protein, and lactose plotted by using the combined data for both groups. There were no differences in milk composition between ewes housed under a 16 -h photoperiod and ewes housed under a naturally declining photoperiod, but percentage of lipid was affected by time $(P \leq 0.001)$, albeit inconsistently.

20 per group) contained, on average, $6.1 \pm 0.05 \%$ lipid, $4.8 \pm 0.02 \%$ protein, and $5.4 \pm 0.01 \%$ lactose $(n=309$ samples).

Time (week) affected mean ewe weight $\left[\mathrm{F}_{(7,1428)}=\right.$ $219.485, P \leq 0.001]$ and the condition of the ewe $\left[\mathrm{F}_{(7,1428)}\right.$ $=29.085, P \leq 0.001]$. There were interactions between time and treatment for ewe weight $\left[\mathrm{F}_{(7,1428)}=14.260, P\right.$ $\leq 0.001]$ and the condition of the ewe $\left[\mathrm{F}_{(7,1428)}=3.006, P\right.$ $=0.004]$, although, in each case, these differences were not consistent (Figure 4). The mean weights of ewes housed under a long-day photoperiod was $75.4 \pm 1.0$ $\mathrm{kg}$ at the beginning of this experiment and $79.4 \pm 1.0$ $\mathrm{kg} 8$ wk later $\left[\mathrm{F}_{(7,567)}=52.465, P \leq 0.001\right]$ and, on average, gained $0.072 \mathrm{~kg} / \mathrm{d}$. Similarly, ewes housed under a naturally declining day length weighed $74.9 \pm 0.9 \mathrm{~kg}$ at the beginning of this experiment and $81.1 \pm 0.9 \mathrm{~kg} 8$ wk later $\left[\mathrm{F}_{(7,525)}=146.697, P \leq 0.001\right]$ and, on average, gained $0.112 \mathrm{~kg} / \mathrm{d}$. Mean BCS of ewes housed under a long-day photoperiod were $2.9 \pm 0.05$ and $3.0 \pm 0.04$, and for ewes housed under a naturally declining day length, mean BCS were $2.8 \pm 0.07$ and $3.2 \pm 0.05$ at the beginning and end of this experiment, respectively.

\section{DISCUSSION}

These data show that milk yield in Australian crossbred ewes was affected by manipulating the photoperiod during lactation. Specifically, housing ewes under a 16-h photoperiod increased milk yield, an effect that was evident after $2 \mathrm{wk}$ of exposure to the increased photoperiod. This stimulatory effect of photoperiod on milk yield in ewes was similar to results in cows, although there was a slightly different time frame of response between species. In cows, the response to long days typically develops after 3 to $4 \mathrm{wk}$ (Dahl and Petitclerc, 2003). In the current study, ewes under a long-day photoperiod produced $15.4 \%$ more milk than control ewes after 8 wh of treatment. Another laboratory reported a $25.3 \%$ increase in milk yield in the Sarda breed of dairy ewe, but, in this case, ewes were exposed to a long-day photoperiod during late pregnancy (Bocquier et al., 1997). This may indicate a role for the long-day photoperiod to increase the growth of parenchymal tissue during mammogenesis, in particular the proliferation, differentiation, and persistency of mammary epithelial cells, thereby increasing milk yield in the ewe. Milk yield in dairy cows is affected by the interactions between mammogenesis and photoperiod (Dahl and Petitclerc, 2003; Wall et al., 2005a,b), but similar data in the dairy ewe are lacking. Exposing ewes to a long-day photoperiod during late pregnancy (Bocquier et al., 1997) may have a more pronounced and persistent effect on milk yield than manipulating the photoperiod during an established lactation. If this is the case, the smaller magnitude of increase in milk yield in ewes exposed to long days in the current study compared with those in the study of Bocquier et al. (1997) may be because, in our experiment, photoperiod could affect galactopoiesis, but not mammogenesis. Alternatively, the crossbred ewes in our experiment may not be substantially affected by season, which is consistent with reports that crossbred sheep display intermediate

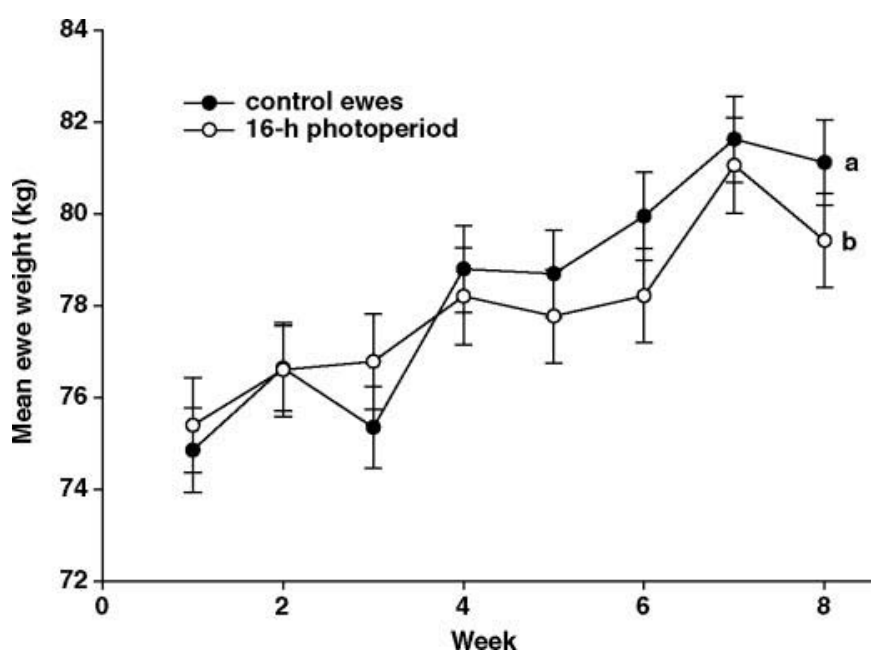

Figure 4. Mean $( \pm$ SEM) ewe weight $(\mathrm{kg})$ in ewes housed under a 16-h photoperiod and ewes housed under a naturally declining day length during the 8 wk of this experiment. Ewe weights were affected by time $(P \leq 0.001)$, and in each group, ewes were heavier at the end of the experiment $(P<0.001$ in both cases), but there were no differences between the groups. 
levels of seasonality with respect to reproduction (Lincoln et al., 1990; Hamadeh et al., 1998). Furthermore, in the current study, photoperiod for the control ewes was considered as a fixed factor, whereas in reality, it was continuous [declining at a rate of $1 \mathrm{~min} / \mathrm{d}$ until the winter solstice on June 22, 2007 (0932 h light, $1428 \mathrm{~h}$ dark)]. The lack of control of the short-day photoperiod may have altered the effect on milk yield compared with studies in which ewes were housed in facilities that permitted the hours of both darkness and light to be controlled, because ewes may become increasingly refractory to a short-day photoperiod (Woodfill et al., 1994). Nevertheless, our results illustrate that Australian crossbred ewes responded to $16 \mathrm{~h}$ of artificial lighting by increasing daily milk production.

Increasing the photoperiod also stimulated basal prolactin secretion. Plasma prolactin concentrations increased in ewes exposed to long days after $6 \mathrm{wk}$ of treatment and were approximately 3 times greater compared with plasma prolactin concentrations of ewes housed under a naturally declining day length. A sharp rise in prolactin secretion occurred in both groups (wk 4) and may reflect the presence of a stressor, because blood sampling was performed in an area away from the dairy but near other activities. The rise in prolactin in response to long days is predictable (Dahl et al., 2000). However, the treatment of cows with exogenous prolactin does not affect milk production (Knight, 2001), nor does treatment with drugs to reduce circulating prolactin abolish lactation in ewes (Hooley et al., 1978) or cows (Knight, 2001), indicating that basal levels of prolactin are not the limiting galactopoietic hormone in dairy animals, especially in comparison with growth hormone (Leibovich et al., 2001). Under most physiological conditions, except late pregnancy and lactation (Grattan and Averill, 1995), prolactin secretion is regulated by dopamine. However, the seasonal control of prolactin secretion by melatonin occurs independently of input from the hypothalamus (Lincoln and Clarke, 2000), and melatonin is thought to exert its effects on the anterior pituitary via a yet to be identified prolactin-releasing factor in the pars tuberalis (Hazlerigg et al., 2001; Lincoln et al., 2006). Treatment with subcutaneous melatonin implants during long days decreases milk production in cows by $23 \%$ (Auldist et al., 2006), and the time taken for changes in prolactin secretion and milk production to occur [6 and $7 \mathrm{wk}$, respectively, in our study, and 5 and 6 wk, respectively, in the study by Auldist et al. (2006)] is consistent with the observation that induction or recovery from melatonin-induced sensitization of the pars tuberalis is a slow, protein synthesis-dependent process (Hazlerigg et al., 1994).
We expected that the quality of the milk between the experimental groups would be different, but we found no predictable changes in milk composition. Previous studies have reported that the protein content of the milk was reduced under long days compared with short days, whereas the lipid in the milk remained unchanged (Bocquier et al., 1990) or was lower under a long-day photoperiod (Bocquier et al., 1997). The protein content of the milk of these ewes was lower compared with that of other breeds used for dairying, and was lower than expected for the East Friesian breed (6.21\% protein), although milk lipid content was comparable (6.64\% lipid; Bencini and Pulina, 1997). The partitioning of nutrients toward increasing body mass and the improvement in body condition may explain this result. Milk protein and lipid also tend to be lower at this stage of lactation compared with the very beginning and end of lactation (Bencini and Pulina, 1997). Further sampling and analysis of milk throughout lactation may be needed to determine whether these estimates are representative for the breed.

\section{CONCLUSIONS}

Daily milk production was increased after 2 wk of exposure to long days, illustrating a stimulatory effect of photoperiod on milk production in Australian crossbred dairy ewes. Plasma prolactin concentrations increased 3-fold, especially during the final 2 wk of the experiment, whereas milk composition was not affected. Because the photoperiod was altered during lactation, the effect on milk yield was probably due to an effect on galactopoiesis rather than on mammogenesis. It is possible that a greater increase in milk production could be achieved if long photoperiods were imposed during late pregnancy.

\section{ACKNOWLEDGMENTS}

We thank the staff at Meredith Dairy (Meredith, Australia) for their assistance. This study was supported by a Rural Industries Research and Development Corporation (RIRDC, Barton, Australia) of Australia-New Industries Grant.

\section{REFERENCES}

Auldist, M. J., S.-A. Turner, C. D. McMahon, and C. G. Prosser. 2006. Effects of melatonin on the yield and composition of milk from grazing dairy cows in New Zealand. J. Dairy Res. 74:52-57.

Barrell, G. K., L. A. Thrun, M. E. Brown, C. Viguie, and F. J. Karsch. 2000. Importance of photoperiodic signal quality to entrainment of the circannual reproductive rhythm of the ewe. Biol. Reprod. 63:769-774. 
Bencini, R., and G. Pulina. 1997. The quality of sheep milk: A review. Aust. J. Exp. Agric. 37:485-504.

Bocquier, F., G. Kann, and M. Theriez. 1990. Relationships between secretory patterns of growth hormone, prolactin and body reserves and milk yield in dairy ewes under different photoperiod and feeding conditions. Anim. Prod. 51:115-125.

Bocquier, F., S. Ligios, G. Molle, and S. Casu. 1997. Effect of photoperiod on milk yield, milk composition and voluntary food intake in lactating dairy ewes. Ann. Zootech. 46:427-438.

Dahl, G. E., B. A. Buchanan, and H. A. Tucker. 2000. Photoperiodic effects on dairy cattle: A review. J. Dairy Sci. 83:885-893.

Dahl, G. E., and D. Petitclerc. 2003. Management of photoperiod in the dairy herd for improved production and health . J. Anim. Sci. 81(Suppl. 3):11-17.

Gootwine, E., and G. E. Pollott. 2000. Factors affecting milk production in improved Awassi dairy ewes. Anim. Sci. 71:607-615.

Grattan, D. R., and R. L. Averill. 1995. Absence of short-loop autoregulation of prolactin during late pregnancy in the rat. Brain Res. Bull. 36:413-416.

Hamadeh, S. K., E. Barbour, M. Abi Said, K. Daadaa, and C. G. Tarraf. 1998. Reproductive performance, progesterone serum, and milk production in spring postpartum Awassi and Finn $\times$ Texel $\times$ Awassi ewes. J. Agric. Sci. 131:347-351.

Hazlerigg, D. G., M. H. Hastings, and P. J. Morgan. 1994. The recovery of ovine pars tuberalis cells from melatonin-induced sensitization is a slow, protein synthesis-dependent phenomenon. J. Endocrinol. 142:127-138.

Hazlerigg, D. G., P. J. Morgan, and S. Messager. 2001. Decoding photoperiodic time and melatonin in mammals: What can we learn from the pars tuberalis? J. Biol. Rhythms 16:326-335.

Hooley, R. D., J. J. Campbell, and J. K. Findlay. 1978. The importance of prolactin for lactation in the ewe. J. Endocrinol. 79:301-310.

Knight, C. H. 2001. Overview of prolactin's role in farm animal lactation. Livest. Prod. Sci. 70:87-93.

Leibovich, H., A. Gertler, F. Bazer, and E. Gootwine. 2001. Effects of recombinant ovine placental lactogen and recombinant ovine growth hormone on growth of lambs and milk production of ewes. Livest. Prod. Sci. 68:79-86.

Lincoln, G. A., and I. J. Clarke. 2000. Role of the pituitary gland in the development of photorefractoriness and generation of long-term changes in prolactin secretion in rams. Biol. Reprod. $62: 432-438$
Lincoln, G. A., I. J. Clarke, R. A. Hut, and D. G. Harzlerigg. 2006. Characterizing a mammalian circannual pacemaker. Science 314:1941-1944

Lincoln, G. A., C. E. Lincoln, and A. S. McNeilly. 1990. Seasonal cycles in blood plasma concentrations of FSH inhibin and testosterone, and testicular size in rams of wild, feral and domesticated breeds of sheep. J. Reprod. Fertil. 88:623-633.

Lindsay, D. R., and J. Skerritt. 2003. Improved breeding for dairy goats and milking sheep: Guidelines for the development of national breeding plans. Rural Ind. Res. Dev. Corp. Publ. No. 02/150. CanPrint Communications, Fyshwick, Australia.

McNeilly, A. S., and P. Andrews. 1974. Purification and characterization of caprine prolactin. J. Endocrinol. 60:359367.

National Health and Medical Research Council. 2004. Australian Code of Practice for the Care and Use of Animals for Scientific Purposes. 7th ed. Natl. Health Med. Res. Counc., Commonwealth Sci. Ind. Res. Org., Aust. Res. Counc., and Aust. Vice-Chancellor's Committee, Canberra, Australia.

Ortavant, R., F. Bocquier, J. Pelletier, J. P. Ravault, J. Thimonier, and P. Volland-Nail. 1988. Seasonality of reproduction in sheep and its control by photoperiod. Aust. J. Biol. Sci. 41:69-85.

Pollott, G. E., and E. Gootwine. 2004. Reproductive performance and milk production of Assaf sheep in an intensive management system. J. Dairy Sci. 87:3690-3703.

Svennersten-Sjaunja, K., and K. Olsson. 2005. Endocrinology of milk production. Domest. Anim. Endocrinol. 29:241-258.

Wall, E. H., T. L. Auchtung, G. E. Dahl, S. E. Ellis, and T. B. McFadden. 2005a. Exposure to short day photoperiod during the dry period enhances mammary growth in dairy cows. J. Dairy Sci. 88:1994-2003.

Wall, E. H., T. L. Auchtung, G. E. Dahl, and T. B. McFadden. 2005b. Short-day photoperiod during the dry period decreases expression of suppressors of cytokine signalling in mammary gland of dairy cows. J. Dairy Sci. 88:3145-3148.

Woodfill, C. J. I., N. L. Wayne, S. M. Moenter, and F. J. Karsch. 1994. Periodic synchronisation of a circannual rhythm of sheep: Identification of season-specific time cues. Biol. Reprod. 50:965976. 